\title{
Virulence and Molecular Analyses Support Asexual Reproduction of Puccinia striiformis f. sp. tritici in the U.S. Pacific Northwest
}

\author{
P. Cheng and X. M. Chen
}

First and second authors: Department of Plant Pathology, Washington State University, Pullman 99164-6430; and second author: United States Department of Agriculture-Agricultural Research Service, Wheat Genetics, Quality, Physiology, and Disease Research Unit, Pullman, WA 99164-6430.

Accepted for publication 18 April 2014.

\begin{abstract}
Cheng, P., and Chen, X. M. 2014. Virulence and molecular analyses support asexual reproduction of Puccinia striiformis f. sp. tritici in the U.S. Pacific Northwest. Phytopathology 104:1208-1220.

Wheat stripe rust, caused by Puccinia striiformis f. sp. tritici, occurs every year and causes significant yield losses in the U.S. Pacific Northwest (PNW). A large number of $P$. striiformis $\mathrm{f}$. tritici races are identified every year and predominant races have changed rapidly. Barberry and mahonia plants, which have been identified under controlled conditions as alternate hosts for the fungus, are found in the region. However, whether sexual reproduction occurs in the P. striiformis f. sp. tritici

single stripe of uredia was made in 26 fields in the PNW in 2010. In total, 270 isolates obtained from the PNW collection, together with 66 isolates from 20 other states collected in the same year, were characterized by virulence tests and simple sequence repeat (SSR) markers. In total, 21 races and 66 multilocus genotypes (MLGs) were detected, of which 15 races and 32 MLGs were found in the PNW. Cluster analysis with the SSR marker data revealed two genetic groups, which were significantly correlated to the two virulence groups. The analyses of genotype/individual ratio, multilocus linkage disequilibrium, and heterozygosity strongly supported asexual reproduction for the pathogen population in the PNW, as well as other regions of the United States.
\end{abstract} population under natural conditions is not clear. To determine the reproduction mode of the $P$. striiformis $\mathrm{f}$. sp. tritici population using virulence and molecular markers, a systematic collection of leaf samples with a
Additional keywords: genetic recombination, mutation.
Puccinia striiformis Westend. f. sp. tritici Erikss. is an obligate biotrophic fungus causing wheat stripe rust, one of the most important diseases worldwide. The $P$. striiformis f. sp. tritici life cycle was previously believed to be semimacrocyclic, consisting of only uredial, telial, and basidial stages on cereal crop and grass hosts (10,51). Mutation and somatic hybridization through karyogamy that may lead to chromosomal reassortment are considered as possible mechanisms creating genetic diversity $(10,30,51,58)$. However, Berberis spp. were recently identified by Jin et al. (32) as alternate hosts for $P$. striiformis f. sp. tritici. The heteroecious macrocyclic lifecycle, consisting of all five spore (pycnial, aecial, uredial, telial, and basidial) stages of $P$. striiformis f. sp. tritici parasitizing the primary host wheat and alternate host barberry, was confirmed in our lab under controlled conditions (56) and in China by Zhao et al. (59). In addition to barberry, Oregon grape (Mahonia spp.), which naturally grow as wild plants in hills and mountain foots and also are planted as ornamental plants in the U.S. Pacific Northwest (PNW), including Washington, Oregon, and Idaho, was also identified as an alternate host under controlled conditions (54).

Thus far, sexual reproduction for stripe rust fungi was only demonstrated from naturally infected barberry plants for bluegrass stripe rust, which is caused by a different species $(P$. pseudostriiformis [syn. P. striiformis f. sp. poae]) (36) in Minnesota (32) and at an extremely low frequency for $P$. striiformis $\mathrm{f}$. sp. tritici in China (59). In contrast, the important role of Berberis

Corresponding author: X. M. Chen; E-mail address: xianming@wsu.edu

http://dx.doi.org/10.1094/PHYTO-11-13-0314-R

This article is in the public domain and not copyrightable. It may be freely reprinted with customary crediting of the source. The American Phytopathological Society, 2014. and Mahonia spp. as alternate hosts for $P$. graminis f. sp. tritici in the stem rust epidemics has been recognized since Craigie discovered the role of pycinia in sexual reproduction of the stem rust fungus in 1927 (18). In the PNW, aeciospores produced on barberry and mahonia plants are essential for stem rust development on wheat and barley (56), and the sexual reproduction on the alternate hosts generates high virulence diversity (46). However, it is not clear whether alternate hosts play any role in the epidemiology and genetic diversity of the $P$. striiformis $\mathrm{f}$. sp. tritici populations in the PNW and the rest of the United States.

The populations of $P$. striiformis f. sp. tritici have been intensively studied using virulence tests and various molecular markers $(5,10,22,28,29,37,50)$. Several studies revealed genetic recombination in certain populations but could not determine whether it was through a sexual process $(6,19,39)$. The high genetic diversity and high rate of $P$. striiformis f. tritici telial production detected in the Tianshui region of Gansu province in China made the authors suggest the existence of a sexual cycle in the stripe rust population (39). Another study with samples also collected from Gansu, China supported the hypothesis that the reproductive mode of the pathogen is not strictly clonal (19). Genetic recombination, although it was not clear whether it resulted from a sexual or asexual process, was detected among isolates of a $P$. striiformis f. sp. tritici population from Pakistan (6). An attempt was made to connect the production of sexspecific structure telia with the genetic diversity of stripe rust populations from different geographic origins (2). With the observation of high telial production and genetic diversity in the $P$. striiformis f. sp. tritici populations in China, Nepal, and Pakistan, an extensive discussion was made regarding to the evolution of sex, center of origin, and distribution of alternate hosts for the stripe rust fungus (2). Although telial production is a condition for sexual reproduction that generally generates high 
diversity, high diversity does not necessarily result from sexual reproduction because many other mechanisms such as mutation and somatic hybridization can generate high diversity, and environmental and host plant conditions can maintain high diversity.

In the United States, $>150$ races of $P$. striiformis $\mathrm{f}$. sp. tritici have been identified since the 1960s $(16,33,34,52)$. From 2000 to 2009 , the number of races in each year ranged from 18 to 42 , with an average of 31 , and the highest number of races was always detected in the PNW (16,52). These numbers are larger than in any other country where $P$. striiformis f. sp. tritici races have been reported, indicating a greater diversity of the pathogen in the United States, particularly the PNW. Early molecular studies using random amplified polymorphic DNA (RAPD) markers also revealed a high genetic diversity of the U.S. P. striiformis f. sp. tritici population $(13,14)$. The large number of races and high genetic diversity made the initial incentive for us to determine reproduction mode for $P$. striiformis $\mathrm{f}$. $\mathrm{sp}$. tritici in this region before the discovery of Berberis spp. as alternate hosts in 2010 (32).

Temperature and humidity are the two most important environmental factors for the infection and growth of the stripe rust fungus and development of the disease when the pathogen and susceptible host plants are available $(10,51)$. Low night temperatures and dew formation are favorable to stripe rust infection. The PNW has weather conditions and cropping systems favorable to stripe rust epidemics. Host plants are always available for stripe rust infection by urediniospores and development due to the long growing season of both spring and winter wheat crops. A recent study using historical weather and stripe rust data demonstrated that the PNW is one of the key regions for P. striiformis $\mathrm{f}$. $\mathrm{sp}$. tritici to oversummer and overwinter (49). Although eradication has been conducted in 1940s to 1970 s, barberry plants, mainly Berberis vulgaris L., are still found in the eastern PNW, especially the Palouse region, including Whitman and Spokane Counties of Washington and Latah County of Idaho $(40,56)$. In this region, stem rust infection in wheat and barley fields is always associated with heavy infection of rust on barberry plants, including high levels of stem rust infections in 2009, 2010, and $2012(46,56)$. Because of the sexual reproduction of the stem rust fungus ( $P$. graminis f. sp. tritici), a great diversity of $P$. graminis f. sp. tritici races was identified in the region, even in a single wheat or barley field $(31,46)$.

The co-existence of barberry plants and $P$. striiformis f. sp. tritici made the Palouse region of the PNW an ideal area for studying the role of barberry and the reproduction mode of the pathogen under natural conditions. Because several Berberis spp. were discovered as alternate hosts for $P$. striiformis $\mathrm{f}$. sp. tritici in 2010 (32), we have been testing aecial samples from barberry and Oregon grape on wheat plants and using species-specific markers to determine biological and climatic factors for sexual reproduction of $P$. striiformis f. sp. tritici $(54,56)$. Parallel to the sexual approach, the present study was conducted to determine the reproduction mode of the $P$. striiformis $\mathrm{f}$. $\mathrm{sp}$. tritici urediniospore population from wheat fields through virulence testing and molecular markers using an adequate sampling strategy. The analyses of virulence and molecular marker data using various suitable population genetics and statistical programs should provide an adequate estimate of the genetic diversity and mode of reproduction for $P$. striiformis f. sp. tritici. Such information should be useful for a better understanding of the epidemiology and improving the control of the disease.

\section{MATERIALS AND METHODS}

Stripe rust sampling and urediniospore multiplication. Stripe rust collections were made mostly in commercial wheat fields during the stripe rust season in May to July 2010, which was also parallel to rust infections on barberry plants. In total, 270 samples were collected from 26 fields in the PNW (Washington, Idaho, and Oregon), with an average of 10 samples in each field (Fig. 1; Table 1). The Palouse region, covering $\approx 12,500 \mathrm{~km}^{2}$ and including Whitman and Spokane Counties in Washington and Latah County in Idaho, was sampled more intensively (17 fields) because barberry bushes have been found in the region. The distance between fields was at least $5 \mathrm{~km}$. Each sample consisted of a single leaf bearing a single stripe of uredia, which was presumably produced from infection by a single urediniospore or aeciospore. The collections were made during the early development of stripe rust in most of the PNW locations in order to obtain single-stripe isolates and a maximal diversity of the pathogen. There was a distance of at least $50 \mathrm{~m}$ between samples in a single wheat field to avoid duplication of any original isolate during the season. An additional 66 P. striiformis f. sp. tritici samples from 20 other states were randomly picked for comparison (Fig. 1).

Each leaf sample was washed with water, placed on a wet filter paper in a petri dish, and incubated for 1 to 2 days in a growth chamber at a diurnal temperature cycle gradually changing from $4^{\circ} \mathrm{C}$ at 2:00 a.m. to $20^{\circ} \mathrm{C}$ at 2:00 p.m. with a cycle of $16 \mathrm{~h}$ of light and $8 \mathrm{~h}$ of darkness to generate fresh urediniospores. The fresh urediniospores were inoculated with a fine brush onto two-leafstage seedlings of 'Nugaines' wheat that is susceptible to all $P$. striiformis f. sp. tritici races identified thus far in the United States $(15,16)$. The inoculated plants were incubated in a dew chamber at $10^{\circ} \mathrm{C}$ for $24 \mathrm{~h}$ without light and grown in a growth chamber. To prevent cross contamination, plants inoculated with different isolates were separated with plastic booths. Urediniospores produced from a single sample were vacuum collected with a custom-made glass collector. Increased urediniospores were dried and kept in a desiccator at $4^{\circ} \mathrm{C}$ for use in virulence tests and DNA extraction.

Virulence tests. The virulence pattern for each isolate was determined by testing urediniospores on the new set of differentials, each carrying $\operatorname{Yrl}, \operatorname{Yr} 5, \mathrm{Yr} 6, \mathrm{Yr} 7, \mathrm{Yr} 8, \mathrm{Yr} 9, \mathrm{Yr} 10, \mathrm{Yr} 15$, Yr17, Yr24, Yr27, Yr32, Yr43, Yr44, YrSP, YrTr1, YrExp2, or YrTye (53). Seedlings at the two-leaf stage were inoculated with urediniospores mixed with talc (Sigma-Aldrich, St. Louis) at a ratio of 1:20. Inoculated plants were placed in a dew chamber for $24 \mathrm{~h}$ at $10^{\circ} \mathrm{C}$ without light and then moved to a growth chamber. Infection types (ITs) were recorded 18 to 20 days after inoculation using a 0 -to-9 scale $(15,34)$. In this study, we did not have intermediate ITs 3 to 6 ; therefore, ITs 0 to 2 were considered avirulent (A) and 7 to 9 virulent (V).

Molecular characterization. DNA was extracted from dried urediniospores following a modified protocol (3). DNA concentration was determined using an ND-1000 spectrophotometer (Bio-Rad, Hercules, CA). The following 20 simple sequence repeat (SSR) primer pairs were selected based on their polymorphism among $P$. striiformis f. sp. tritici isolates: CPSO2, CPS04, CPS08, and CPS13 (9); PstP001, PstP002, PstP003, PstP004, PstP005, PstP006, PstP007, PstP025, PstP029, PstP030, PstP031, and PstP033 (17); RJ18, RJ20, and RJ21 (21); and RJ8N (4). In order to use fluorescence to detect polymerase chain reaction (PCR) products, an M13 tag (5'-CACGACGTTGTA AAACGAC) was added to the $5^{\prime}$ end of each forward primer (48).

PCR amplifications were done following the protocol described in a previous study (17). The sizes of the PCR products were estimated using capillary electrophoresis on an ABI3730 Genotyper (Applied Biosystems, Foster City, CA). The internal molecular weight standard for ABI3730 was Genescan 445-LIZ (Applied Biosystems). Allele sizes in base pairs were called using the GeneMapper v3.7 software (Applied Biosystems).

Data analyses. To determine relationships among races, avirulent ITs were converted to 0 and virulent ITs to 1 following the method of Chen et al. $(13,14)$. A neighbor-joining tree was 
constructed by the NTsyspc $2.21 \mathrm{~L}$ program using the Dice coefficient. Bootstrap analysis was used to determine the robustness of branches of the dendrograms with the Winboot program (41). Correlation between the multilocus genotypes (MLGs) and virulence data was determined by comparison of the two similarity matrices using MXCOMP, a matrix comparison program of the NTsyspc 2.21L. The existence of substructures in the population was assessed on the microsatellite data using STRUCTURE (43). The program STUCTURE HARVESTER (http://taylor0.biology.ucla.edu/structureHarvester/) was used to determine the best fit number of clusters $(\mathrm{K})$ by generating a plot of the change in mean likelihood values per K $(20,23)$.

To test for the rate of clonal reproduction, three analyses were performed with all MLGs in the Palouse population (with
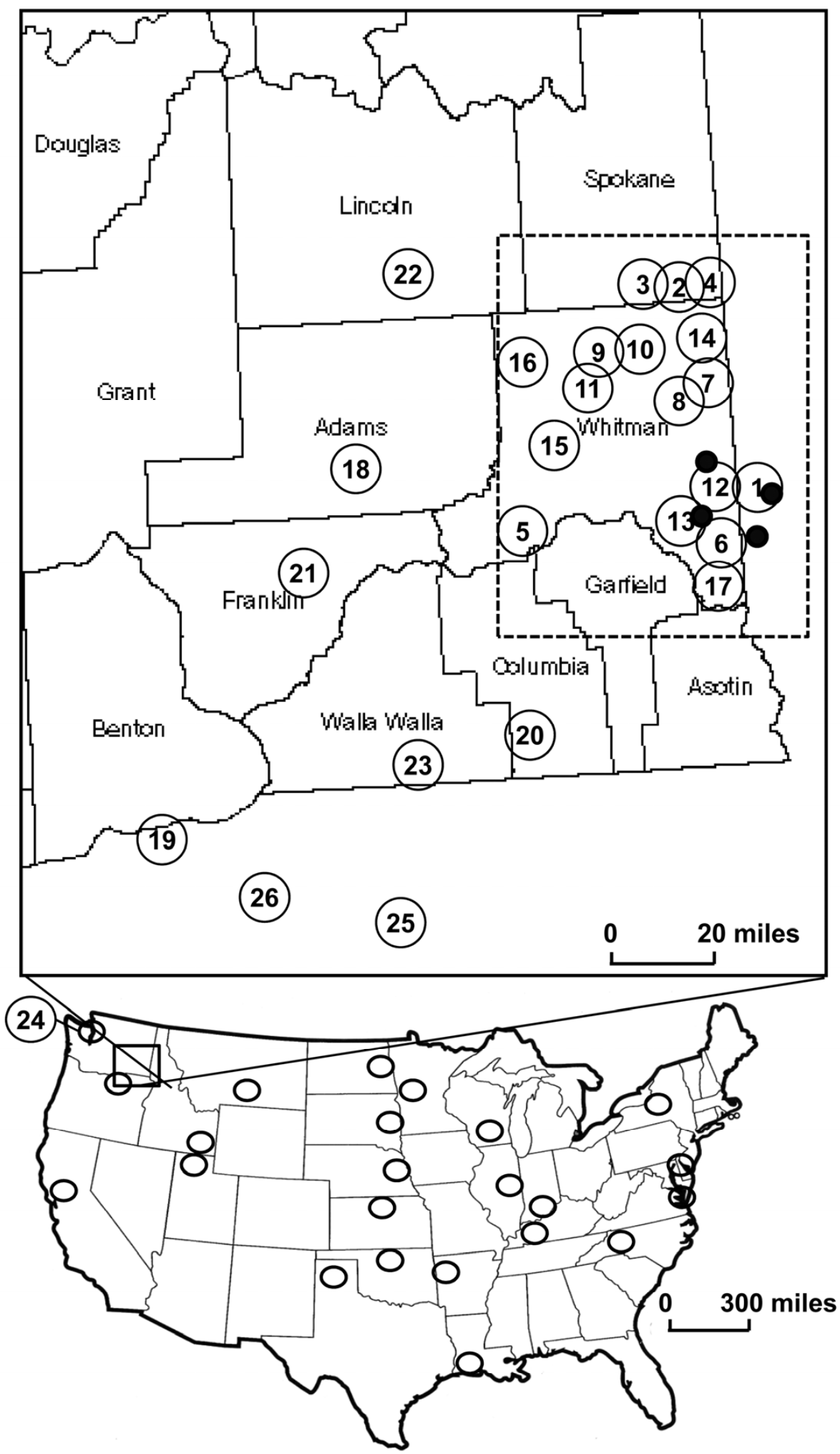

Fig. 1. Map showing Puccinia striiformis f. sp. tritici samples collected from the Pacific Northwest (PNW) and 20 states in the United States in 2010 . Circles mark the 26 PNW fields where single stripe samples were collected and the numbers in the circles correspond to the field number in Table 3 . The Palouse region is indicated by the broken line rectangle. The four black dots indicated locations with presence of barberry bushes. 
presence of barberry) and the non-Palouse PNW population (Fig. 1). First, the normalized index of association was estimated and the null hypothesis $r_{D}=0$ was tested with 1,000 permutations using the MULTILOCUS 2.2 program (1). Second, the ratios of genotype/number of isolates $(\mathrm{G} / \mathrm{N})$ were computed for each field in the Palouse region and the non-Palouse PNW region. A value close to 0 is characteristic of a strictly clonal population, in which all individuals share the same genotype, whereas a value close to 1 indicates that all individuals in the population have distinct genotypes, as expected under sexual reproduction and genetic recombination (8). Third, the inbreeding coefficients of both populations were measured. The maximum deviation from random mating was described and calculated as $F_{\text {IS }}$ using FSTAT software version $2.9 .3(25,57)$. Observed heterozygosity $\left(\mathrm{H}_{\mathrm{o}}=\right.$ number of heterozygosities/N) and expected heterozygosity $\left[\mathrm{H}_{\mathrm{e}}=\right.$ $\left.1-\Sigma p_{i}^{2}\right]$, where $p_{i}=$ the frequency of the $i$ th MLG, were calculated using software GENALEX 6 (42). $F$ statistics and heterozygosity values were calculated for each MLG and for each population separately. Deviations from Hardy-Weinberg expectations and unbiased estimates of $F_{\text {IS }}(57)$ were determined using FSTAT, version 2.9.3 (25) permuting alleles 1,000 times among individuals. Analysis of molecular variance (AMOVA) was conducted to assess genetic variation within and among the $P$. striiformis f. sp. tritici populations with the software package Arlequin, version 3.11 (24).

\section{RESULTS}

Virulence variation. The populations from the Palouse (with known barberry bushes) and non-Palouse PNW (without known barberry bushes) regions had very similar virulence patterns (Fig. 2 ), indicating that barberry bushes did not affect $P$. striiformis $\mathrm{f}$. sp. tritici race compositions. More than $80 \%$ of the isolates from these two populations were virulent to $\operatorname{YrTye}, \operatorname{Yrl}, \mathrm{Yr} 17, \mathrm{Yr} 7$, Yr27, YrExp2, Yr43, Yr9, Yr44, Yr6, and Yr8. A moderate frequency was found for virulence to $\operatorname{Yr} \operatorname{Tr} 1(41 \%)$ and a few low frequencies between 4 and $11 \%$ to $\operatorname{Yr} 24, \operatorname{Yr} 10, \operatorname{Yr} 32$, and $\mathrm{YrSP}$. Interestingly, no isolate from the non-PNW U.S. collection was virulent to $\operatorname{Yrl}, \mathrm{YrSP}$, or YrTye, and virulence frequency on $\operatorname{YrTr} 1$ doubled compared with the PNW population. None of the isolates were virulent to $\operatorname{Yr} 5$ or $\operatorname{Yr} 15$, indicating these resistance genes are still effective.

In total, 21 races were detected from the 336 isolates collected throughout the United States. Among these races, PSTv-4, PSTV9, and PSTV-13 were detected only in the Palouse region; PSTV-8 only in the non-Palouse PNW; six (PSTv-12, 30, 31, 32, 35, and 39) only in the non-PNW United States; four (PSTv-36, 37, 38, and 41 ) in all three regions; and the remaining seven (PSTv-7, 11, $14,16,17,34$, and 40) in two of these regions (Table 2). The most frequent race in the Palouse region was PSTV-11 $(50.56 \%)$ followed by PSTv-14 (25.00\%), which were different only by being avirulent and virulent on $\operatorname{YrTr}$. These predominant races had similar frequencies in the non-Palouse PNW but were not detected in the non-PNW United States. In the non-PNW United States, the most predominant race was PSTV-37 (54.55\%) followed by PSTV-36 (12.12\%), which differed only by its virulence or avirulence to $\operatorname{Yr} 17$. These two races were also detected in the PNW. All other races had $<8.00 \%$ frequency in each of the regions. The high frequencies of the predominant races indicated that the $P$. striiformis $\mathrm{f}$. $\mathrm{sp}$. tritici isolates have been produced mostly, if not absolutely, from asexual reproduction.

The cluster analysis of the races revealed two major virulence groups (VGs) (Fig. 3). VG 1 consisted of 10 races (PSTV-4, 7, 8, $9,11,12,13,14$, and 17) and VG 2 consisted of 11 races (PSTV$16,30,31,32,34,35,36,37,38,39,40$, and 41). The main differences were that races in VG 1 were all virulent to $\mathrm{Yrl}$, most virulent to YrTye, and few virulent to $\operatorname{YrSP}$, whereas none of the races in VG 2 were virulent to these resistance genes. Most PNW isolates (84\%) belonged to races in VG 1 and most isolates from

TABLE 1. Number of isolates, races, virulence groups (VGs), multilocus genotypes (MLGs), and molecular groups (MGs) in collection regions

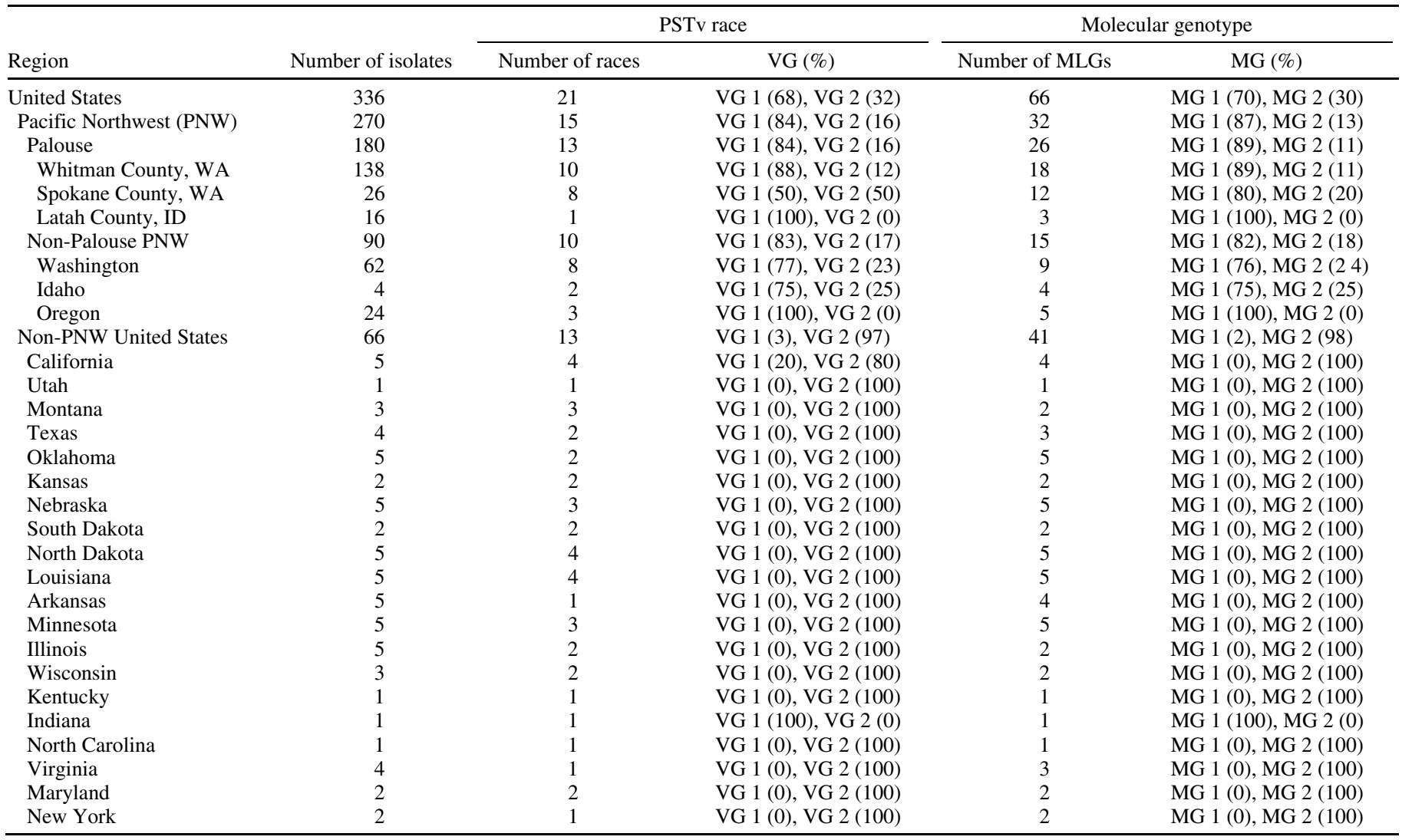


the non-PNW United States (97\%) belonged to races in VG 2 (Tables 1 and 2).

The races and the numbers of isolates in individual PNW fields are shown in Table 3. Among the 26 fields, 10 had only one race, 5 had two races, 6 had three races, and 5 had the highest four races. All 16 isolates in the field (number 1) surrounding barberry bushes near Potlatch in the Latah county of Idaho were the same race, PSTV-14, one of the most predominant race in the PNW. Similar results were observed in three other fields near barberry bushes (fields 6, 12, and 13) (Table 3). These indicated that the barberry bushes with abundant rust aecia did not affect the num- ber of $P$. striiformis $\mathrm{f}$. sp. tritici races in the surrounding wheat field.

Genetic variation. With the 20 SSR markers, 66 MLGs were identified from the 336 tested isolates (Table 4). Of the 66 MLGs, $26(39.39 \%)$ were detected in the Palouse region, $15(22.73 \%)$ in the non-Palouse PNW, and $41(62.12 \%)$ in the non-PNW United States (Tables 1 and 4). The most common MLGs in the Palouse region were G19 (49.44\%), G1 (11.67\%), and G12 (11.11\%), while the remaining 23 MLGs had only 0.56 to $3.89 \%$ frequencies. In the non-Palouse PNW, the most common MLGs were G19 (50.00\%) and G12 (23.33\%), and the remaining 24

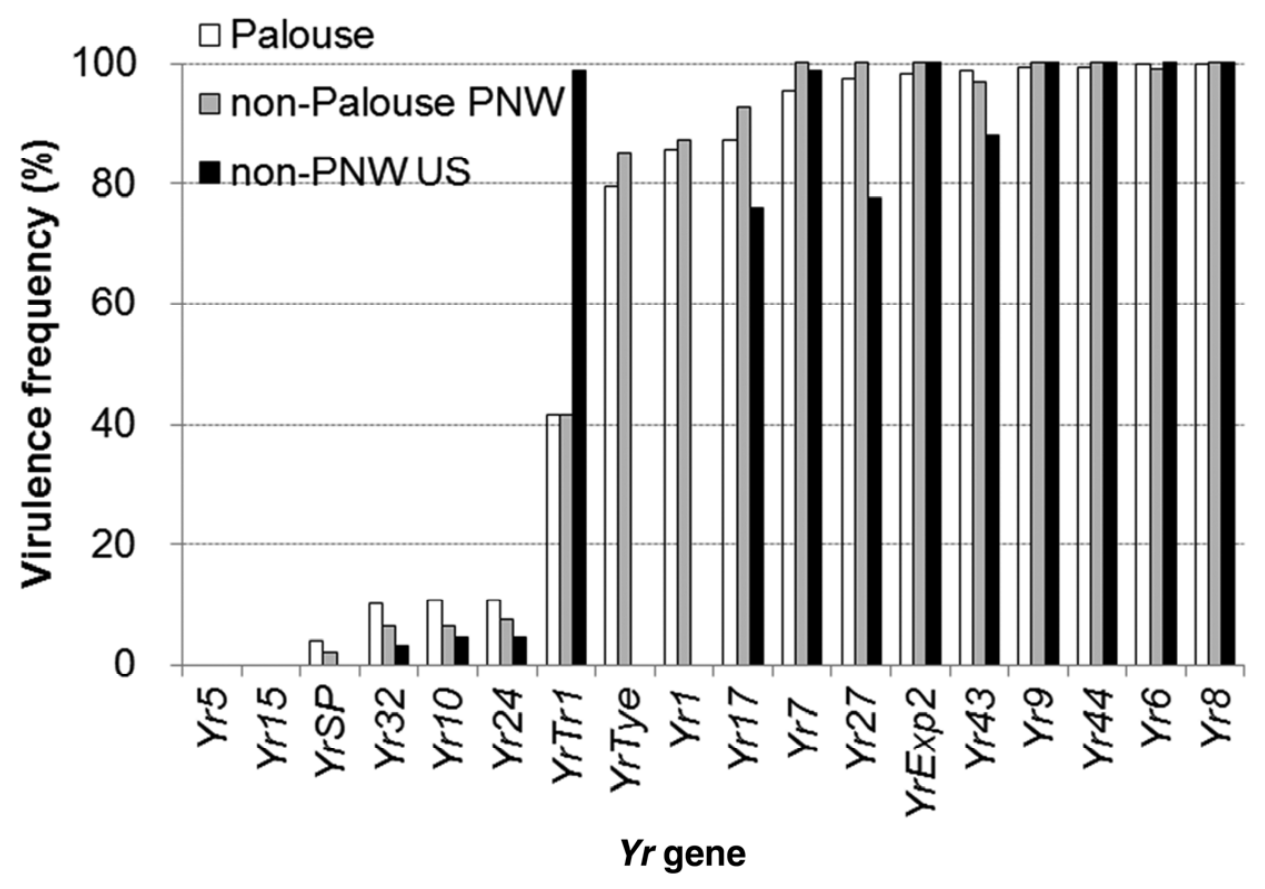

Fig. 2. Frequencies of Puccinia striiformis f. sp. tritici virulence to the $18 Y r$-gene lines in the Palouse, the non-Palouse Pacific Northwest (PNW), and the nonPNW United States.

TABLE 2. Puccinia striiformis f. sp. tritici races and their virulence formula; virulence group (VG); number of isolates in the Palouse region, the non-Palouse Pacific Northwest (PNW), and the non-PNW United States; total number in the study $(N)$; and total frequency (\%)

\begin{tabular}{|c|c|c|c|c|c|c|c|c|c|c|}
\hline \multirow[b]{2}{*}{ Race $^{a}$} & \multirow[b]{2}{*}{ Virulence formula $(Y r \text { gene })^{\mathrm{a}}$} & \multirow[b]{2}{*}{ VG } & \multicolumn{2}{|c|}{ Palouse } & \multicolumn{2}{|c|}{ Non-Palouse PNW } & \multicolumn{2}{|c|}{ The non-PNW US } & \multicolumn{2}{|c|}{ Total } \\
\hline & & & $N$ & $\%$ & $N$ & $\%$ & $N$ & $\%$ & $N$ & $\%$ \\
\hline PSTv-11 & 1,6,7,8,9,17,27,43,44,Еxp2,Туе & 1 & 91 & 50.56 & 49 & 54.44 & 0 & 0.00 & 140 & 41.67 \\
\hline PSTv-14 & $1,6,7,8,9,17,27,43,44, \operatorname{Tr} 1, \operatorname{Exp} 2$, Туе & 1 & 45 & 25.00 & 23 & 25.56 & 0 & 0.00 & 68 & 20.24 \\
\hline PSTv-17 & $1,6,7,8,9,17,27,43,44, \mathrm{SP}, \operatorname{Exp} 2, \mathrm{Tye}$ & 1 & 5 & 2.78 & 2 & 2.22 & 0 & 0.00 & 7 & 2.08 \\
\hline PSTv-16 & $1,6,7,8,9,10,24,32,43,44, \operatorname{Tr} 1, \operatorname{Exp} 2$ & 1 & 4 & 2.22 & 0 & 0.00 & 1 & 1.52 & 5 & 1.49 \\
\hline PSTv-4 & $1,6,9,17,27$, SP,Tyе & 1 & 1 & 0.56 & 0 & 0.00 & 0 & 0.00 & 1 & 0.30 \\
\hline PSTv-12 & 1,6,7,8,9,17,43,44,Tr1,Exp2,Туе & 1 & 0 & 0.00 & 0 & 0.00 & 1 & 1.52 & 1 & 0.30 \\
\hline PSTv-40 & $6,7,8,9,10,24,27,32,43,44, \operatorname{Tr} 1, \operatorname{Exp} 2$ & 2 & 13 & 7.22 & 1 & 1.11 & 0 & 0.00 & 14 & 4.17 \\
\hline PSTv-37 & $6,7,8,9,17,27,43,44, \operatorname{Tr} 1, \operatorname{Exp} 2$ & 2 & 6 & 3.33 & 5 & 5.56 & 36 & 54.55 & 47 & 13.99 \\
\hline PSTv-36 & $6,7,8,9,27,43,44, \operatorname{Tr} 1, \operatorname{Exp} 2$ & 2 & 4 & 2.22 & 1 & 1.11 & 8 & 12.12 & 13 & 3.87 \\
\hline PSTv-38 & $6,7,8,9,17,24,27,43,44, \operatorname{Tr} 1, \operatorname{Exp} 2$ & 2 & 1 & 0.56 & 1 & 1.11 & 1 & 1.52 & 3 & 0.89 \\
\hline PSTv-41 & $6,7,8,9,10,17,24,27,32,43,44, \operatorname{Tr} 1, \operatorname{Exp} 2$ & 2 & 1 & 0.56 & 5 & 5.56 & 1 & 1.52 & 7 & 2.08 \\
\hline PSTV-39 & $6,7,8,9,10,17,27,43,44, \operatorname{Tr} 1, \operatorname{Exp} 2$ & 2 & 0 & 0.00 & 0 & 0.00 & 1 & 1.52 & 1 & 0.30 \\
\hline
\end{tabular}

${ }^{a}$ Race name and virulence formula follow the description by Wan and Chen (53). The set of 18 wheat $Y r$ single-gene differentials included AvSYr1NIL ( $Y r 1$ ), AvSYr5NIL ( $Y r 5)$, AvSYr6NIL (Yr6), AvSYr7NIL (Yr7), AvSYr8NIL (Yr8), AvSYr9NIL (Yr9), AvSYr10NIL (Yr10), AvSYr15NIL (Yr15), AvSYr17NIL (Yr17), AvSYr24NIL (Yr24), AvSYr27NIL (Yr27), AvSYr32NIL (Yr32), AvS/IDO377s (F3-41-1) (Yr43), AvS/Zak (1-1-35-line1) (Yr44), AvSYrSPNIL (YrSP), AvSYrTr1NIL (YrTr1), AvS/Exp 1/1-1 Line 74 (YrExp2), and Tyee (YrTye) (12). 


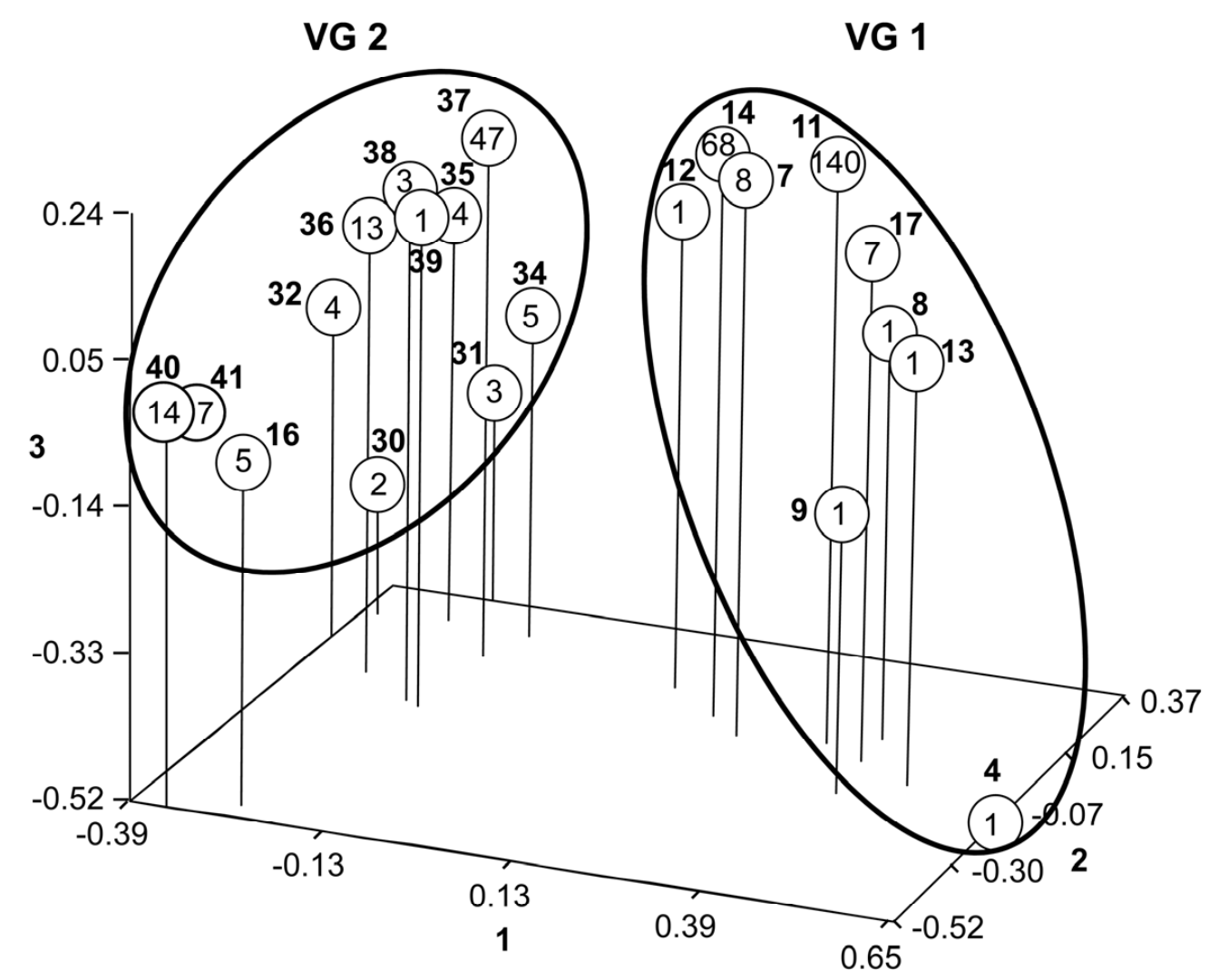

Fig. 3. Three-dimensional plot of 21 Puccinia striiformis f. sp. tritici races using principal coordinates analysis. VG 1 and VG 2 indicate two virulence groups. The number in a circle represents the number of isolates and the number outside the circle is the PSTv race name.

TABLE 3. Locations of wheat fields sampled, races, and multilocus genotypes (MLGs) of Puccinia striiformis f. sp. tritici in the U.S. Pacific Northwest (PNW)

\begin{tabular}{|c|c|c|c|c|c|c|c|c|}
\hline Field $^{\mathrm{a}}$ & Location & County & State $^{b}$ & Type $^{\mathrm{c}}$ & $\begin{array}{c}\text { PSTV race } \\
\text { (number of isolates) }\end{array}$ & $\begin{array}{c}\text { MLGs } \\
\text { (number of isolates) }\end{array}$ & $\mathrm{G} / \mathrm{N}^{\mathrm{d}}$ & $\mathrm{F}_{\mathrm{IS}}{ }^{\mathrm{e}}$ \\
\hline \multicolumn{9}{|c|}{ Palouse region } \\
\hline $1 *$ & Potlatch & Latah & ID & $\mathrm{C}$ & $14(16)$ & $1(10), 19(5), 22(1)$ & 0.19 & $0.240^{*}$ \\
\hline 2 & Latah & Spokane & WA & $\mathrm{C}$ & $16(2), 36(1), 40(6), 41(1)$ & $7(2), 8(2), 10(4), 33(1), 50(1)$ & 0.50 & 0.023 \\
\hline 3 & North Pine & Spokane & WA & $\mathrm{C}$ & $11(2), 16(2), 17(1), 37(1)$ & $6(1), 11(1), 19(2), 23(1), 63(1)$ & 0.83 & 0.011 \\
\hline 4 & Latah East & Spokane & WA & $\mathrm{C}$ & $9(1), 11(8), 17(1)$ & $12(5), 19(3), 21(1), 63(1)$ & 0.40 & 0.066 \\
\hline 5 & Central Ferry west & Whitman & WA & $\mathrm{E}$ & $14(19), 11(1)$ & $1(5), 19(14), 15(1)$ & 0.15 & $0.397^{*}$ \\
\hline $6^{*}$ & Whitlow farm & Whitman & WA & $\mathrm{E}$ & $11(11)$ & $19(10), 12(1)$ & 0.18 & $-0.222^{*}$ \\
\hline 7 & Farmington-1 & Whitman & WA & $\mathrm{C}$ & $11(3), 40(7)$ & $10(7), 19(3)$ & 0.20 & -0.161 \\
\hline 8 & Farmington-2 & Whitman & WA & $\mathrm{E}$ & $11(10)$ & $19(10)$ & 0.10 & $-1.000 * *$ \\
\hline 9 & Malden & Whitman & WA & $\mathrm{C}$ & $7(7)$ & $17(7)$ & 0.14 & $-1.000 * *$ \\
\hline 10 & Rosalia & Whitman & WA & $\mathrm{C}$ & $11(2), 14(4), 36(3)$ & $1(4), 19(2), 50(3)$ & 0.33 & 0.129 \\
\hline 11 & St John city & Whitman & WA & $\mathrm{C}$ & $11(10)$ & $12(10)$ & 0.10 & $-1.000 * *$ \\
\hline $12 *$ & Palouse & Whitman & WA & $\mathrm{C}$ & $11(9), 14(1)$ & $1(1), 12(2), 19(7)$ & 0.30 & $0.312 *$ \\
\hline $13 *$ & SW Colfax & Whitman & WA & $\mathrm{C}$ & $11(11)$ & $19(10), 3(1)$ & 0.18 & -0.152 \\
\hline 14 & Tekoa & Whitman & WA & $\mathrm{C}$ & $11(2), 14(2), 17(1), 37(5)$ & $1(1), 12(1), 19(2), 23(5), 63(1)$ & 0.50 & -0.079 \\
\hline 15 & Endicott & Whitman & WA & $\mathrm{C}$ & $4(1), 11(7), 13(1), 17(1)$ & $5(2), 12(1), 19(6), 63(1)$ & 0.40 & -0.007 \\
\hline 16 & Lamont & Whitman & WA & $\mathrm{C}$ & $11(5), 14(3), 17(1), 38(1)$ & $19(7), 49(1), 53(1), 63(1)$ & 0.40 & 0.001 \\
\hline 17 & Colton & Whitman & WA & $\mathrm{C}$ & $11(10)$ & $19(10)$ & 0.10 & $-1.000 * *$ \\
\hline \multicolumn{9}{|c|}{ Non-Palouse PNW } \\
\hline 18 & Lind & Adams & WA & $\mathrm{E}$ & $11(8), 14(1), 40(1)$ & $7(1), 19(9)$ & 0.20 & -0.132 \\
\hline 19 & Horse Heaven Hill & Benton & WA & $\mathrm{C}$ & $11(2), 34(2), 38(1)$ & $19(2), 30(1), 42(2)$ & 0.60 & -0.015 \\
\hline 20 & Highway-12 & Columbia & WA & $\mathrm{C}$ & $11(10)$ & $19(10)$ & 0.10 & $-1.000 * *$ \\
\hline 21 & Connell & Franklin & WA & $\mathrm{C}$ & $11(4), 17(1), 37(5)$ & $12(4), 23(5), 63(1)$ & 0.30 & -0.117 \\
\hline 22 & Harrington & Lincoln & WA & $\mathrm{E}$ & $11(7), 14(2), 17(1)$ & $1(1), 12(4), 19(4), 63(1)$ & 0.40 & 0.104 \\
\hline 23 & Walla Walla & Walla Walla & WA & $\mathrm{C}$ & $11(2), 14(10)$ & $12(2), 19(10)$ & 0.17 & -0.143 \\
\hline 24 & Mt. Vernon & Skagit & WA & $\mathrm{E}$ & $41(5)$ & $33(5)$ & 0.20 & $-1.000 * *$ \\
\hline 25 & Pendleton & Umatilla & OR & $\mathrm{E}$ & $8(1), 14(10)$ & $21(1), 19(10)$ & 0.18 & -0.186 \\
\hline 26 & Hermiston & Umatilla & OR & $\mathrm{E}$ & $11(13)$ & $12(11), 13(1), 16(1)$ & 0.23 & $1.000 * *$ \\
\hline
\end{tabular}

a Fields close to the barberry bushes were marked with an asterisk (*).

b ID = Idaho, WA = Washington, and OR = Oregon.

${ }^{c}$ Experimental (E) or commercial (C) field.

d Ratio of genotype/number of isolates.

${ }^{\text {e }} \mathrm{F}_{\mathrm{IS}}$ values significant departure from zero at the $5 \%$ level are marked with an asterisk (*) and at $1 \%$ level are marked with two asterisks (**). 
TABLE 4. Frequencies of multilocus genotypes (MLGs) and molecular groups (MG) in various Puccinia striiformis f. sp. tritici populations

\begin{tabular}{|c|c|c|c|c|c|c|c|c|}
\hline \multirow[b]{3}{*}{ MLG } & \multicolumn{8}{|c|}{ Number $(N)$ and percentage $(\%)$ of isolates in each MLG and $\mathrm{MG}^{\mathrm{a}}$} \\
\hline & \multicolumn{2}{|c|}{ Palouse } & \multicolumn{2}{|c|}{ Non-Palouse PNW } & \multicolumn{2}{|c|}{ Non-PNW United States } & \multicolumn{2}{|c|}{ United States } \\
\hline & $N$ & $\%$ & $N$ & $\%$ & $N$ & $\%$ & $N$ & $\%$ \\
\hline \multicolumn{9}{|l|}{ MG 1} \\
\hline G01 & 21 & 11.67 & 1 & 1.11 & 0 & 0.00 & 22 & 6.55 \\
\hline G02 & 1 & 0.56 & 0 & 0.00 & 0 & 0.00 & 1 & 0.30 \\
\hline G03 & 1 & 0.56 & 0 & 0.00 & 0 & 0.00 & 1 & 0.30 \\
\hline G04 & 1 & 0.56 & 0 & 0.00 & 0 & 0.00 & 1 & 0.30 \\
\hline G05 & 2 & 1.11 & 0 & 0.00 & 0 & 0.00 & 2 & 0.60 \\
\hline G06 & 1 & 0.56 & 0 & 0.00 & 0 & 0.00 & 1 & 0.30 \\
\hline G07 & 2 & 1.11 & 1 & 1.11 & 0 & 0.00 & 3 & 0.89 \\
\hline G08 & 2 & 1.11 & 0 & 0.00 & 0 & 0.00 & 2 & 0.60 \\
\hline G09 & 1 & 0.56 & 0 & 0.00 & 0 & 0.00 & 1 & 0.30 \\
\hline G10 & 4 & 2.22 & 0 & 0.00 & 0 & 0.00 & 4 & 1.19 \\
\hline G11 & 1 & 0.56 & 0 & 0.00 & 0 & 0.00 & 1 & 0.30 \\
\hline G12 & 20 & 11.11 & 21 & 23.33 & 0 & 0.00 & 41 & 12.20 \\
\hline G13 & 4 & 2.22 & 1 & 1.11 & 0 & 0.00 & 5 & 1.49 \\
\hline G14 & 0 & 0.00 & 1 & 1.11 & 0 & 0.00 & 1 & 0.30 \\
\hline G15 & 0 & 0.00 & 1 & 1.11 & 0 & 0.00 & 1 & 0.30 \\
\hline G16 & 0 & 0.00 & 1 & 1.11 & 0 & 0.00 & 1 & 0.30 \\
\hline G17 & 7 & 3.89 & 0 & 0.00 & 1 & 1.52 & 8 & 2.38 \\
\hline G18 & 0 & 0.00 & 1 & 1.11 & 0 & 0.00 & 1 & 0.30 \\
\hline G19 & 89 & 49.44 & 45 & 50.00 & 0 & 0.00 & 134 & 39.88 \\
\hline G20 & 1 & 0.56 & 0 & 0.00 & 0 & 0.00 & 1 & 0.30 \\
\hline G21 & 1 & 0.56 & 1 & 1.11 & 0 & 0.00 & 2 & 0.60 \\
\hline G22 & 1 & 0.56 & 0 & 0.00 & 0 & 0.00 & 1 & 0.30 \\
\hline Subtotal & 160 & 88.89 & 74 & 82.22 & 1 & 1.52 & 235 & 69.94 \\
\hline \multicolumn{9}{|l|}{ MG 2} \\
\hline G23 & 6 & 3.33 & 5 & 5.56 & 1 & 1.52 & 12 & 3.57 \\
\hline $\mathrm{G} 24$ & 2 & 1.11 & 0 & 0.00 & 2 & 3.03 & 4 & 1.19 \\
\hline $\mathrm{G} 25$ & 0 & 0.00 & 0 & 0.00 & 2 & 3.03 & 2 & 0.60 \\
\hline G26 & 0 & 0.00 & 0 & 0.00 & 1 & 1.52 & 1 & 0.30 \\
\hline G27 & 0 & 0.00 & 0 & 0.00 & 1 & 1.52 & 1 & 0.30 \\
\hline G28 & 0 & 0.00 & 0 & 0.00 & 1 & 1.52 & 1 & 0.30 \\
\hline G29 & 0 & 0.00 & 0 & 0.00 & 1 & 1.52 & 1 & 0.30 \\
\hline G30 & 0 & 0.00 & 1 & 1.11 & 1 & 1.52 & 2 & 0.60 \\
\hline G31 & 0 & 0.00 & 0 & 0.00 & 2 & 3.03 & 2 & 0.60 \\
\hline G32 & 0 & 0.00 & 0 & 0.00 & 1 & 1.52 & 1 & 0.30 \\
\hline G33 & 1 & 0.56 & 5 & 5.56 & 12 & 18.18 & 18 & 5.36 \\
\hline G34 & 0 & 0.00 & 0 & 0.00 & 2 & 3.03 & 2 & 0.60 \\
\hline G35 & 0 & 0.00 & 1 & 1.11 & 0 & 0.00 & 1 & 0.30 \\
\hline G36 & 0 & 0.00 & 0 & 0.00 & 1 & 1.52 & 1 & 0.30 \\
\hline G37 & 0 & 0.00 & 0 & 0.00 & 1 & 1.52 & 1 & 0.30 \\
\hline G38 & 0 & 0.00 & 0 & 0.00 & 1 & 1.52 & 1 & 0.30 \\
\hline G39 & 0 & 0.00 & 0 & 0.00 & 5 & 7.58 & 5 & 1.49 \\
\hline G40 & 0 & 0.00 & 0 & 0.00 & 1 & 1.52 & 1 & 0.30 \\
\hline G41 & 0 & 0.00 & 0 & 0.00 & 1 & 1.52 & 1 & 0.30 \\
\hline G42 & 0 & 0.00 & 2 & 2.22 & 1 & 1.52 & 3 & 0.89 \\
\hline G43 & 0 & 0.00 & 0 & 0.00 & 2 & 3.03 & 2 & 0.60 \\
\hline G44 & 0 & 0.00 & 0 & 0.00 & 1 & 1.52 & 1 & 0.30 \\
\hline G45 & 0 & 0.00 & 0 & 0.00 & 1 & 1.52 & 1 & 0.30 \\
\hline G46 & 0 & 0.00 & 0 & 0.00 & 1 & 1.52 & 1 & 0.30 \\
\hline G47 & 0 & 0.00 & 0 & 0.00 & 1 & 1.52 & 1 & 0.30 \\
\hline G48 & 0 & 0.00 & 0 & 0.00 & 1 & 1.52 & 1 & 0.30 \\
\hline G49 & 1 & 0.56 & 0 & 0.00 & 0 & 0.00 & 1 & 0.30 \\
\hline G50 & 4 & 2.22 & 0 & 0.00 & 5 & 7.58 & 9 & 2.68 \\
\hline G51 & 0 & 0.00 & 0 & 0.00 & 1 & 1.52 & 1 & 0.30 \\
\hline G52 & 0 & 0.00 & 0 & 0.00 & 2 & 3.03 & 2 & 0.60 \\
\hline G53 & 1 & 0.56 & 0 & 0.00 & 0 & 0.00 & 1 & 0.30 \\
\hline G54 & 0 & 0.00 & 0 & 0.00 & 1 & 1.52 & 1 & 0.30 \\
\hline G55 & 0 & 0.00 & 0 & 0.00 & 1 & 1.52 & 1 & 0.30 \\
\hline G56 & 0 & 0.00 & 0 & 0.00 & 1 & 1.52 & 1 & 0.30 \\
\hline G57 & 0 & 0.00 & 0 & 0.00 & 1 & 1.52 & 1 & 0.30 \\
\hline G58 & 0 & 0.00 & 0 & 0.00 & 1 & 1.52 & 1 & 0.30 \\
\hline G59 & 0 & 0.00 & 0 & 0.00 & 1 & 1.52 & 1 & 0.30 \\
\hline G60 & 0 & 0.00 & 0 & 0.00 & 1 & 1.52 & 1 & 0.30 \\
\hline G61 & 0 & 0.00 & 0 & 0.00 & 1 & 1.52 & 1 & 0.30 \\
\hline G62 & 0 & 0.00 & 0 & 0.00 & 1 & 1.52 & 1 & 0.30 \\
\hline G63 & 5 & 2.78 & 2 & 2.22 & 0 & 0.00 & 7 & 2.08 \\
\hline G64 & 0 & 0.00 & 0 & 0.00 & 1 & 1.52 & 1 & 0.30 \\
\hline G65 & 0 & 0.00 & 0 & 0.00 & 1 & 1.52 & 1 & 0.30 \\
\hline G66 & 0 & 0.00 & 0 & 0.00 & 1 & 1.52 & 1 & 0.30 \\
\hline Subtotal & 20 & 11.11 & 16 & 17.78 & 65 & 98.48 & 101 & 30.06 \\
\hline Total & 180 & 53.57 & 90 & 26.79 & 66 & 19.64 & 336 & 100.00 \\
\hline
\end{tabular}

a PNW = Pacific Northwest. 
MLGs had only 1.11 to $5.56 \%$ frequencies. In the non-PNW United States, the most frequent MLGs were G33 (18.18\%), G39 (7.58\%), and G50 (7.58\%), while the remaining 38 MLGs had only 1.52 to $3.03 \%$ frequencies. Nationwide, the top five MLGs were G19 (39.88\%), G12 (12.20\%), G01 (6.55\%), G33 (5.36\%), and $\mathrm{G} 23$ (3.57\%); the remaining 61 genotypes had 0.30 to $2.68 \%$ frequencies. High frequencies of very few MLGs and low frequencies of most of the MLGs indicated asexual reproduction of the $P$. striiformis f. sp. tritici population in each of the regions.

The numbers of MLGs in the individual fields ranged from one to five (Table 3 ). Most of the fields had $<0.50$ genotype/individual $(\mathrm{G} / \mathrm{N})$ ratios. Four fields in the Palouse region had a $\mathrm{G} / \mathrm{N}$ ratio $>0.50$ but none of them were near barberry bushes. Similar results were obtained by the $F$ statistics analysis; only a few fields had $F_{\text {IS }}$ values close to 0 . However, the field (number 1) surrounding barberry bushes in Latah County, ID had three MLGs, with MLG 1 predominant $(62.50 \%)$, and had low $\mathrm{G} / \mathrm{N}$ ratio $(0.19)$ and a high $F_{\text {IS }}$ value significantly different from 0 , which did not indicate sexual reproduction.

Genetic characteristics of the populations in different regions are summarized in Table 5 by various analyses of the molecular data. The $\mathrm{G} / \mathrm{N}$ ratios for the Palouse region or the PNW region were 0.14 and 0.17 , respectively, suggesting a significant high level of clonal reproduction in the region. Similarly, the $r_{D}$ values (0.33 to 0.62 ) based on either all MLGs or single-copy MLGs, which were all significantly different from $0(P<0.001)$, indicated that the molecular marker loci were in linkage disequilibrium and led to the rejection of the null hypothesis of random mating from sexual reproduction. The low heterozygosity values in the Palouse (0.138) and non-Palouse PNW (0.263) regions suggested strong clonal reproduction. Finally, the nonzero $F_{\text {IS }}$ values for most marker locus analyzed individually and analyzed together (multilocus $F_{\text {IS }}$ ) showed significant heterozygote excess or deficiency, which means deviation from random mating in the Palouse or PNW region, indicating clonal reproduction.

The results of AMOVA indicated that the majority (62.65\%) of the total genetic variation was found within populations and only $35.45 \%$ among populations in the Palouse region, the non-Palouse PNW, and the non-PNW United States (Table 6). The variations both within and among populations were significant $(P<0.01)$. The data indicated significant migration of $P$. striformis $\mathrm{f}$. sp. tritici spores among the regions.

The neighbor-joining tree constructed using the SSR data revealed two major molecular groups (MGs) (Fig. 4A). MG 1 consisted of MLGs G1 to G22 with homozygous genotypes at

TABLE 5. Genetic characteristics of Puccinia striiformis f. sp. tritici populations sampled from Palouse, non-Palouse Pacific Northwest (PNW), and non-PNW United States $^{\mathrm{a}}$

\begin{tabular}{|c|c|c|c|}
\hline Indices $^{\mathrm{b}}$ & Palouse $(n=180)$ & Non-Palouse PNW $(n=90)$ & Non-PNW United States $(n=66)$ \\
\hline \multicolumn{4}{|l|}{ Genotypes } \\
\hline \multicolumn{4}{|l|}{ Linkage disequilibrium } \\
\hline \multicolumn{4}{|l|}{ Heterozygosity } \\
\hline $\mathrm{H}_{\mathrm{o}}$ & 0.138 & 0.263 & 0.477 \\
\hline $\mathrm{SE}$ & 0.041 & 0.044 & 0.074 \\
\hline \multicolumn{4}{|l|}{$\mathrm{F}_{\text {IS }}$ per locus } \\
\hline CPS02 & $0.905^{* *}$ & $0.813^{* *}$ & $0.874 * *$ \\
\hline CPS04 & $0.968^{* *}$ & $0.969 * *$ & $0.921 * *$ \\
\hline CPS08 & $0.870^{* *}$ & $0.519^{* *}$ & $0.909 * *$ \\
\hline CPS13 & -0.056 & -0.130 & $-0.630 * *$ \\
\hline PstP001 & $-0.457 * *$ & $-0.636^{* *}$ & $-0.608 * *$ \\
\hline PstP002 & -0.029 & -0.208 & $-0.608 * *$ \\
\hline PstP025 & $0.681^{* *}$ & 0.097 & $-0.318^{*}$ \\
\hline PstP029 & -0.056 & -0.200 & $-0.523 * *$ \\
\hline PstP030 & $0.457 * *$ & $0.333^{*}$ & -0.152 \\
\hline PstP031 & $1.000^{* *}$ & $0.966^{* *}$ & $0.860^{* *}$ \\
\hline PstP033 & -0.059 & -0.161 & $-0.320 * *$ \\
\hline RJ18 & -0.047 & -0.013 & $-0.417 * *$ \\
\hline RJ20 & $0.657 * *$ & $0.539 * *$ & $0.641 * *$ \\
\hline RJ21 & -0.043 & -0.098 & $-0.451 * *$ \\
\hline RJ8N & $0.366^{*}$ & -0.184 & $-0.523 * *$ \\
\hline $\mathrm{F}_{\text {IS }}$ multilocus & 0.272 & 0.126 & -0.050 \\
\hline SE & 0.112 & 0.112 & 0.142 \\
\hline
\end{tabular}

${ }^{a} \mathrm{~F}_{\mathrm{IS}}$ values significant at the $5 \%$ level are marked with an asterisk $(*)$ and at $1 \%$ level are marked with two asterisks $(* *)$.

${ }^{\mathrm{b}} \mathrm{G} / \mathrm{N}=$ ratio of genotype/number of isolates, $\mathrm{MLG}=$ multilocus genotype, and $\mathrm{SE}=$ standard error.

TABLE 6. Analysis of molecular variance among and within the Puccinia striiformis f. sp. tritici populations in the Palouse region, the non-Palouse Pacific Northwest (PNW), and the non-PNW United States based on the simple sequence repeat marker data ${ }^{\mathrm{a}}$

\begin{tabular}{lrrrrc}
\hline Source & DF & SS & PV $(\%)$ & EV & \\
\hline Among populations & 2 & 556 & 35.45 & 1.35 & $<0.01$ \\
Within population & 333 & 1,641 & 64.55 & 2.45 & $<.01$ \\
Total & 336 & 2,197 & 100.00 & 3.80 & $\ldots$ \\
\hline
\end{tabular}

${ }^{\mathrm{a}} \mathrm{DF}=$ degree of freedom, $\mathrm{SS}=$ sum of squared deviation, $\mathrm{PV}=$ percentage of variance, $\mathrm{EV}=$ estimated variance, and $P=$ probability. 
most loci (AA lineage). Genotypes G23 to G66 that were heterozygous at most SSR loci were MG 2 (AB lineage). In total, $\approx 89 \%$ of the 176 Palouse isolates were grouped to MG 1, 83\% of the 94 non-Palouse PNW isolates were in MG 1, and 78.9\% the 66 nonPNW US isolates were in MG 2. The three MLGs (G1, G19, and G22) detected in the wheat field (number 1) surrounding barberry bushes were clustered in MG 1, indicating that they were genetically similar and likely produced by mutation. The STRUCTURE analysis also determined two populations based on the SSR data, consistent with the MGs in Figure 4B.

Some of the MLGs in Figure 4A corresponded to races in Figure 3. In MG 1, isolates in G12 were all PSTV-11 and isolates of G19 were either PSTv-11 or PSTv-19. In MG 2, G33 corresponded to PSTv-36, PSTv-37, and PSTv-41, which were the most common races in the non-PNW United States. Overall, most PNW isolates were virulent on $\mathrm{Yrl}$ and YrTye. Most nonPNW U.S. isolates were avirulent on $\mathrm{Yrl}$ and YrTye. The comparison of the virulence and molecular matrices using MXCOMP in the NTSYSpc $2.21 \mathrm{~L}$ program showed a moderate but significant correlation coefficient $(r=0.39, P<0.001)$, again indicating clonal reproduction.

\section{DISCUSSION}

Strong clonal structures were detected from randomly sampled isolates in most individual fields, the specific regions, and the United States. Given the G/N ratios of 0.14 and 0.17 in the Palouse and the extended PNW region, respectively, it is very

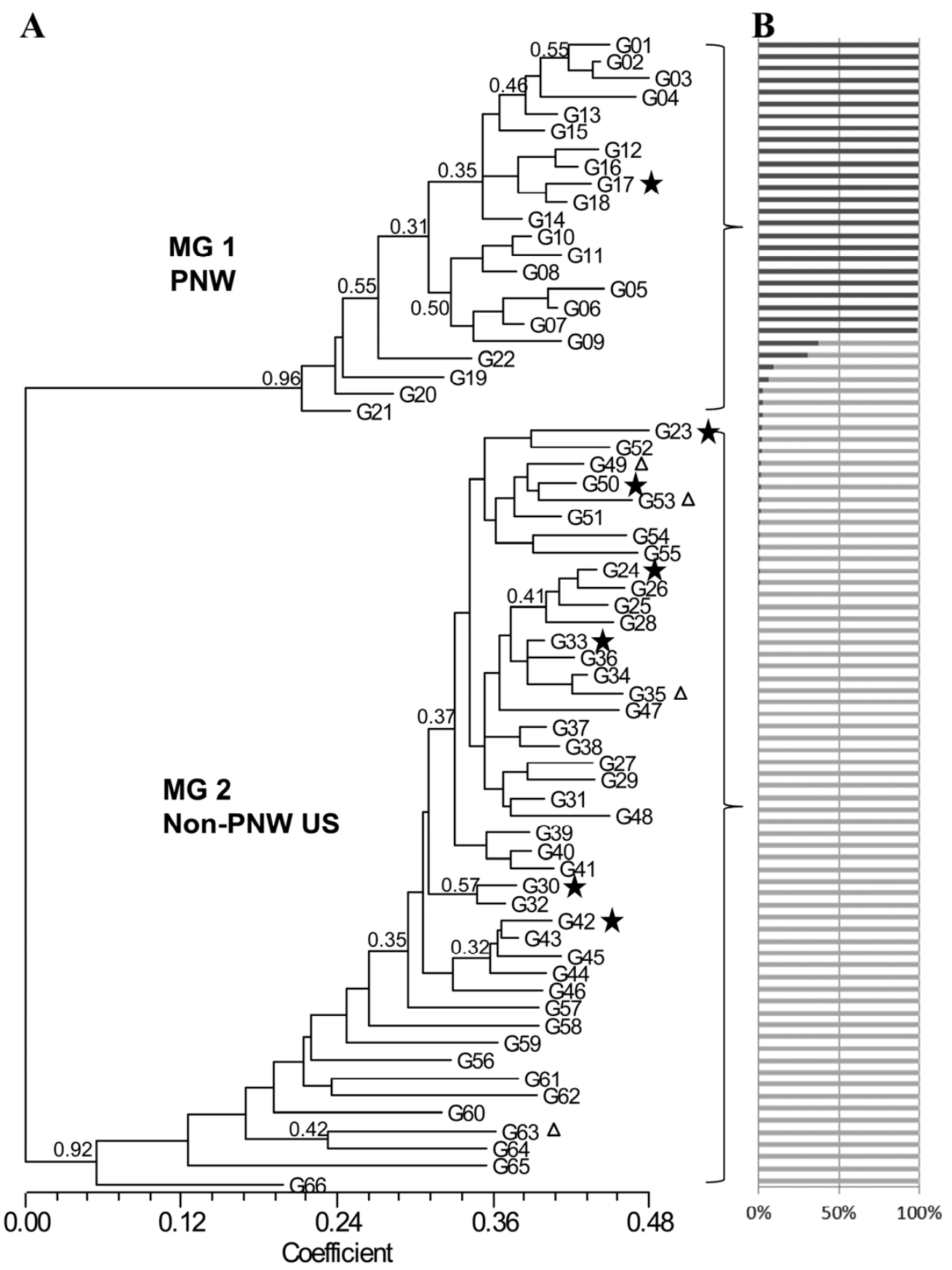

Fig. 4. A, Neighbor-joining tree showing the similarities of 66 multilocus genotypes (MLGs) of Puccinia striiformis f. sp. tritici based on simple sequence repeat data using the NTSYSpc 2.21L program. MG 1 and MG 2 are molecular groups shown in Table 4 . The number at each branch shows the percentage of times the group of isolates in that branch occurred based on 2,000 cycles in bootstrap analysis using the Winboot program. Stars indicate MLGs detected in both Pacific Northwest (PNW) and non-PNW U.S. regions and the triangle indicates MLGs detected only in the PNW region. B, Two subpopulations estimated by STRUCTURE. 
unlikely that sexual reproduction has played an important role in the $P$. striiformis $\mathrm{f}$. sp. tritici population. In the PNW population, 32 MLGs were identified from 270 isolates. This number may seem fairly high compared with the clonal population identified in Europe (29). However, all the MLGs identified in this study belonged to two major MGs that consist of MLGs with high similarities (Fig. 4). Due to the favorable environmental conditions for stripe rust, a large number of grown cultivars, and high diversity of race-specific all-stage resistance and non-race-specific high-temperature adult-plant resistance in the PNW (10), the high diversity of the $P$. striiformis $\mathrm{f}$. sp. tritici population is likely generated by mutation and possibly by introduction and somatic recombination and maintained through clonal reproduction.

Heterozygote excesses and deficiencies observed in both the small Palouse region $\left(r_{D}=0.43\right.$ and 0.33$)$ and the non-Palouse PNW region $\left(\mathrm{r}_{\mathrm{D}}=0.56\right.$ and 0.42$)$ with and without repeated MLGs indicate that the $P$. striiformis $\mathrm{f}$. sp. tritici population is mostly, if not entirely, clonal. In addition, the $F$ statistic values that were significantly different from zero were observed with most SSR loci and the MLGs in the region. All of the analyses rejected the null hypothesis of random mating or sexual reproduction in the Palouse or the PNW region even with the presence of B. vulgaris plants. The virulence analysis also supported the conclusion.

Sexual reproduction generates more races. This is well demonstrated for $P$. graminis f. sp. tritici in the United States, especially in the PNW $(31,44)$. Because of the sexual reproduction on alternate hosts, the PNW population of $P$. graminis f. $\mathrm{sp}$. tritici contains a relatively high number of races compared with the population of the eastern United States (31). Numerous $P$. graminis f. sp. tritici races were detected in the single heavily infected spring barley field in 2007 in Stevens County (46), and many distinct $P$. graminis f. sp. tritici races were identified from the heavily infected winter wheat field (the same Potlatch field in this study) in 2009 (Y. Jin and X. M. Chen, unpublished data). Zhao et al. (59) reported remarkable variation in virulence patterns observed in $>80$ single-uredium $P$. striiformis f. sp. tritici isolates obtained from four aecia collected from naturally infected barberry plants in China. In our lab, we identified 16 different races from 29 urediniospore isolates generated from aecia produced on barberry plants inoculated with germinated teliospores of a single $P$. striiformis f. sp. tritici isolate under controlled conditions (55). In contrast, we were only able to detect one to four races of $P$. striiformis $\mathrm{f}$. sp. tritici in a single field in the present study. Even in the Potlatch field around barberry bushes, we detected only one race (PSTV-14) that was the most predominant race in the PNW (53). The number of races and virulence-avirulence patterns of the races in a single field or in a region suggest that the isolates resulted from asexual reproduction but not sexual reproduction.

If the low number of races in each individual field was due to the selection by stripe rust resistance in the wheat cultivar grown in the fields, the number of races may not correctly indicate the reproduction mode. However, this is not the case for wheat cultivars grown in the PNW, where most commercially grown cultivars have high-temperature adult-plant resistance, which has been demonstrated to be non-race-specific $(10,11,33)$. The number of races identified in the Palouse region or the PNW in the present study was comparable with our studies of race identification (53). Furthermore, all races identified in the present study were also identified in the regular survey.

Clear association of stem rust in wheat fields and nearby barberry plants has been reported in the literature $(31,44,45)$ and frequently observed by the second author in the eastern PNW. For example, stem rust was very severe in a spring barley field and easily observed in some other spring wheat and barley fields in a small valley of Stevens County in eastern Washington in 2007, and barberry bushes with rust were found in the surrounding mountains in the next spring. In 2009, severe stem rust occurred in a winter wheat field surrounding barberry bushes with abundant aecia. The wheat field displayed nice gradients of severity: the closer the wheat plants were to the barberry bushes, the more severe was the stem rust observed on the plants. In 2012, stem rust was most widespread in the eastern PNW but was still limited to the Palouse region because barberry bushes are mainly found in the area. Teliospores are important for $P$. graminis f. sp. tritici to overwinter in the PNW because its urediniospores can hardly survive winters in the region. The second author observed stem rust in a wheat field in south-central Washington (no barberry plants were found or reported in the area) in November 2010 and the stem rust completely disappeared in the subsequent surveys in the following spring. Under the eastern PNW weather conditions, alternate host plants are essential for receiving basidiospores produced from overwintered teliospores and producing aeciospores to start epidemics of stem rust on cereal crops. Because alternate hosts are essential for stem rust epidemics in cereal crops, we predict stem rust mainly based on the severity of rust infection on barberry bushes in spring in the PNW. In contrast, there are no reports or observations of association of stripe rust in wheat fields with rust on nearby barberry bushes. Even in the Potlatch field surrounding barberry bushes, stripe rust occurred scattered throughout the field when we collected samples for the present study. Unlike the stem rust fungus, P. striiformis f. sp. tritici can survive winter as urediniospores on leaves or, more so, as mycelium within infected wheat leaves. In the same field where stem rust was observed in November 2010 in south-central Washington, stripe rust was found in foci of several meters in diameter, and the rust was still active in the subsequent surveys in the following spring and developed into an epidemic in March 2011. Based on previous reports and the present study, $P$. striiformis f. sp. tritici does not need alternative hosts to carry from season to season.

The conclusion of asexual reproduction is supported by molecular markers, which are presumably neutral to selection. In the present study, we used 20 SSR markers which were developed either from expressed sequence tag sequences $(4,9,17)$ or genomic sequences (21), which are scattered throughout the $P$. striiformis f. sp. tritici genome and the genes have not been found to be favorable or unfavorable under any selection. These markers were selected based on their co-dominance because $P$. striiformis f. sp. tritici urediniospores are dikaryotic. The co-dominant SSR markers are desirable over the previously used RAPD $(13,14)$ or amplified fragment length polymorphism $(19,22,28,29)$ for studying dikaryotic populations of $P$. striiformis $\mathrm{f}$. sp. tritici because they allowed us to identify homozygous and heterozygous isolates. The majority of the SSRs used in this study were designed by us and have been demonstrated to possess the power to distinguish different formae speciales and race groups (15-17). The various analyses with the molecular data, including the frequencies of MLGs, G/N ratios, $\mathrm{r}_{\mathrm{D}}$ values, heterozygosity, $F_{\mathrm{IS}}$ values for individual loci and MLGs, structure, and clustering lineages, all support clonal reproduction of the $P$. striiformis $\mathrm{f}$. sp. tritici population in the Palouse or PNW region. Even in the field surrounding barberry bushes, only three very closely related MLGs were detected with a $\mathrm{G} / \mathrm{N}$ ratio clearly different from that expected from random mating. Similar results were also found in three other fields near barberry bushes (fields 6, 12, and 13) (Fig. 1; Table 3). Few fields, including field number 4 and field number 14 in the Palouse region, had a $\mathrm{G} / \mathrm{N}$ ratio $\geq 0.50$ and $F_{\mathrm{IS}}$ values close to zero, which may suggest relatively high genetic variation. However, these fields generally had a small number of isolates and the MLGs were similar. Because these MLGs belong to the two MGs identified in the entire region, they did not likely result from sexual segregation. The generally low genetic variation detected in the fields in the Palouse region is more likely caused by single-step mutations and asexual recombination in the local 
population, and different isolates spread by wind from other regions, rather than by segregation through a sexual reproduction process on the nearby alternate host plants.

Using co-dominant SSR markers, we were able to compare $P$. striiformis $\mathrm{f}$. sp. tritici genotypes by their heterozygosity. MLGs in MG 1 correlated mostly to races in VG 1, which were mostly from the PNW and were more homozygous than those in MG 2, which correlated mostly to races in VG 2 , which were detected throughout the United States. Represented by races PSTv-11 and PSTv-14, which are equivalent to PST-127 that was detected first in California and Washington in 2007 (16), the VG 1 races have become predominant in the PNW. The distinct and highly homozygous group may suggest the race as an introduction (16). The isolates in VG 2 or MG 2 (represented by PSTv-36, PSTv-37, and PSTV-40), presumably present in the United States before MG 1 based on their equivalent races PST-100, PST-102, and PST-114 (16), were highly heterozygous. Both homozygous and heterozygous genotypes can be maintained in the P. striiformis $\mathrm{f}$. sp. tritici population through clonal production. As time goes by, the homozygous isolates could become more and more heterozygous because mutations in one nucleus can be maintained through clonal reproduction.

The majority of PNW isolates belonged to MG 1, with predominantly homozygous loci, and VG 1 , with a wider virulence pattern (virulence on $\mathrm{Yrl}, \mathrm{YrSP}$, and YrTye). The correlation between the MLGs and races is consistent with our study on stripe rust isolates from grasses, which found that PSTV-11 and PSTV-14 (previously PST-127 or PST-139) possess more homozygous loci than other races. In the U.S. PNW, the P. striiformis $\mathrm{f}$. sp. tritici population did not produce abundant telia until the appearance of PST-127 and related races in MG 1, which were first identified in California and Washington in 2007 and, since then, have become predominant in the PNW (16). This group of races produces abundant telia in the fields and also on adult plants under controlled greenhouse conditions. With telia produced in the field and in the greenhouse by this race group, we successfully infected barberry plants and obtained aecium-derived urediniospore isolates with very distinct virulence patterns under the controlled greenhouse conditions compared with what we observed in field-collected samples (55). Therefore, production of telia does not necessarily result in sexual reproduction, although it is a precondition. The non-PNW isolates were older races distributed from the PNW with more heterozygous loci (belonging to MG 2) and less virulence and producing fewer telia. Importantly, analysis of genetic variations for each of the sampled $P$. striiformis $\mathrm{f}$. sp. tritici populations suggested that the two MGs have geographically distinct distributions. Low gene flow between these two populations could be due to the geographic barrier created by the Rocky Mountains because it is hard for the initial inoculum urediniospores to get over the mountains by air. It is also possible that the time was not long enough from 2007, when we detected the races in MG 1 in the western United States (16), to 2010, when the $P$. striiformis f. sp. tritici collection was made for the present study, for the two genetic groups to hybridize asexually to produce hybrid isolates and for the MG 1 isolates to spread to the eastern United States. Similar spatial distribution was also observed in the flax rust pathogen (7). Two distinct lineages, AA (homozygous dominant) and $\mathrm{AB}$ (heterozygous dominant), were identified in the plains and mountains, respectively, including features such that lineage AA formed more telia. Currently, we are conducting studies to characterize historical isolates and those collected after 2010 to determine the origin of the relatively new group and how the $P$. striiformis $\mathrm{f}$. sp. tritici population has evolved in the past. Nevertheless, the present study demonstrated that the two VGs or two MGs are two distinct clonal populations.

Sexual reproduction is not necessarily important for rust fungi, depending upon the climatic conditions and the biology of the fungus. For $P$. graminis, sexual populations normally have existed at cooler latitudes such as the northern United States, Canada, and northern Europe, and at higher elevations farther south, because teliospores germinate better when produced under cool temperatures than under high temperatures (45). Teliospores of P. graminis need to pass through a long period of cold conditions to germinate and produce basidiospores to infect alternate hosts. In Australia, the wheat and rye stem rust fungal populations are considered to be clonally reproduced $(27,38)$. For leaf rust, natural infection of Thalictrum spp., alternate hosts of $P$. triticina, occurs rarely and, thus, they do not play an important role in the origin of new races of the pathogen in North America (47). Through comparison of associations between virulence and molecular markers in clonal lineages and disassociations in sexual population, Liu and Kolmer (35) concluded that no sexual reproduction had occurred to any significant amount in the $P$. triticina population in North America. Similarly, Goyeau et al. (26) reported the clonal reproduction of the leaf rust pathogen in France using a pathotype and molecular genotype association approach. In the present study, we determined clonal reproduction for $P$. striiformis f. sp. tritici in the PNW by testing virulence and molecular markers. We obtained a significant association between the virulence phenotypes and molecular genotypes, and the correlation coefficient $(r=0.39)$ is remarkably similar to that of the clonal $P$. triticina population reported in France $(r=0.37)$ (26). Our study focused on the areas where barberry plants were present and several sampled wheat fields were near the alternate host plants; even so, we did not find barberry to play an important role in stripe rust epidemics or generating races.

Our results strongly indicate that the $P$. striiformis f. sp. tritici populations in the PNW and other regions of the United States are reproduced asexually. If $P$. striiformis $\mathrm{f}$. sp. tritici infection and reproduction occurs on alternate host plants under natural conditions in the PNW, we should be able to detect the fungus directly from infected barberry and mahonia leaves. We have been sampling and testing rust fungi from barberry plants for $P$. striiformis f. sp. tritici in the PNW since the report of barberry as alternate host in 2010 (32). Consistent with the present study, the preliminary results do not show $P$. striiformis f. $\mathrm{sp}$. tritici from barberry plants. We have continued conducting survey and confirmation experiments and, at the same time, we have also conducted experiments to study the biological and ecological characteristics of $P$. striiformis f. sp. tritici telial stage, which will answer why barberry is not important for stripe rust in the PNW.

The present study is the first to show that $P$. striiformis $\mathrm{f}$. sp. tritici isolates collected from fields with the presence of barberry bushes represent asexually reproduced populations. Studying the way that the stripe rust fungus evolves is very important to understand the virulence variation of the pathogen and to conduct better disease management. Our results suggest that barberry does not play a significant role in stripe rust in the PNW. Therefore, disease management should be focused on crop hosts and auxiliary grass hosts. Genetic variations, including virulence variations, resulting from mutation and somatic recombination are selected by crop and grass hosts through clonal reproduction. Therefore, these hosts for urediniospores should be intensively sampled to identify new races. Utilization of non-race-specific resistance, such as high-temperature adult-plant resistance and diverse genes for effective all-stage resistance $(10,11)$, should be key to achieving sustainable control of stripe rust.

\section{ACKNOWLEDGMENTS}

Mention of trade names or commercial products in this publication is solely for the purpose of providing specific information and does not imply recommendation or endorsement by the United States Department of Agriculture (USDA). USDA is an equal opportunity provider and employer. This research was supported by the United States Department 
of Agriculture-Agricultural Research Service (Project Number 534822000-015-00D) and Washington State University (Project Number 13C3061-3925) PPNS Number 0616, Department of Plant Pathology, College of Agricultural, Human, and Natural Resource Sciences, Agricultural Research Center, Project Number WNP00663, Washington State University, Pullman 99164-6430. We thank M. Wang for technical support of the rust DNA extraction; A. Wan for increasing urediniospores and identifying races for some of the stripe rust isolates used in this study; D. See for technical support for using capillary electrophoresis on an ABI3730 Genotyper; and S. Hulbert, T. Peever, and K. Gill for critical review of the manuscript.

\section{LITERATURE CITED}

1. Agapow, P. M., and Burt, A. 2001. Indices of multilocus linkage disequilibrium. Mol. Ecol. Notes 1:101-102.

2. Ali, S., Leconte, M., Walker, A. S., Enjalbert, J., and de Vallavieille-Pope, C. 2010. Reduction in the sex ability of worldwide clonal populations of Puccinia striiformis f. sp. tritici. Fungal Genet. Biol. 47:828-838.

3. Aljanabi, S. M., and Martinez, I. 1997. Universal and rapid salt-extraction of high quality genomic DNA for PCR-based techniques. Nucleic Acids Res. 25:4692-4693.

4. Bahri, B., Leconte, M., de Vallavieille-Pope, C., and Enjalbert, J. 2009. Isolation of ten microsatellite loci in an EST library of the phytopathogenic fungus Puccinia striiformis f. sp. tritici. Conserv. Genet. 10:1425-1428.

5. Bahri, B., Leconte, M., Ouffroukh, A., De Vallavieille-Pope, C., and Enjalbert, J. 2009. Geographic limits of a clonal population of wheat yellow rust in the Mediterranean region. Mol. Ecol. 18:4165-4179.

6. Bahri, B., Shah, S. J. A., Hussain, S., Leconte, M., Enjalbert, J., and de Vallavieille-Pope, C. 2011. Genetic diversity of the wheat yellow rust population in Pakistan and its relationship with host resistance. Plant Pathol. 60:649-660.

7. Barrett, L. G., Thrall, P. H., and Burdon, J. J. 2007. Evolutionary diversification through hybridization in a wild host-pathogen interaction. Evolution 61:1613-1621.

8. Burt, A. 2000. Perspective: Sex, recombination, and the efficacy of selection-Was Weismann right? Evolution 54:337-351.

9. Chen, C. Q., Zheng, W. M., Buchenauer, H., Huang, L. L., Lu, N. H., and Kang, Z. S. 2009. Isolation of microsatellite loci from expressed sequence tag library of Puccinia striiformis f. sp. tritici. Mol. Ecol. Res. 9:236-238.

10. Chen, X. M. 2005. Epidemiology and control of stripe rust [Puccinia striiformis f. sp. tritici] on wheat. Can. J. Plant Pathol. 27:314-337.

11. Chen, X. M. 2013. High-temperature adult-plant resistance, key for sustainable control of stripe rust. Am. J. Plant Sci. 4:608-627.

12. Chen, X. M., Line, R. F., and Jones, S. S. 1995. Chromosomal location of genes for resistance to Puccinia striiformis in winter wheat cultivars Heines VII, Clement, Moro, Tyee, Tres, and Daws. Phytopathology 85:1362-1367.

13. Chen, X. M., Line, R. F., and Leung, H. 1993. Relationship between virulence variation and DNA polymorphism in Puccinia striiformis. Phytopathology 83:1489-1497.

14. Chen, X. M., Line, R. F., and Leung, H. 1995. Virulence and polymorphic DNA relationships of Puccinia striiformis f. sp. hordei to other rusts. Phytopathology 85:1335-1342.

15. Chen, X. M., Moore, M., Milus, E. A., Long, D. L., Line, R. F., Marshall, D., and Jackson, L. 2002. Wheat stripe rust epidemics and races of Puccinia striiformis f. sp. tritici in the United States in 2000. Plant Dis. 86:39-46.

16. Chen, X. M., Penman, L., Wan, A. M., and Cheng, P. 2010. Virulence races of Puccinia striiformis f. sp. tritici in 2006 and 2007 and development of wheat stripe rust and distributions, dynamics, and evolutionary relationships of races from 2000 to 2007 in the United States. Can. J. Plant Pathol. 32:315-333.

17. Cheng, P., Chen, X. M., Xu, L. S., and See, D. R. 2012. Development and characterization of expressed sequence tag-derived microsatellite markers for the wheat stripe rust fungus Puccinia striiformis f. sp. tritici. Mol. Ecol. Res. 12:779-781.

18. Craigie, J. H. 1927. Experiments on sex in rust fungi. Nature 120:116.

19. Duan, X., Tellier, A., Wan, A., Leconte, M., de Vallavieille-Pope, C., and Enjalbert, J. 2010. Puccinia striiformis f. sp. tritici presents high diversity and recombination in the over-summering zone of Gansu, China. Mycologia 102:44-53.

20. Earl, D. A., and VonHoldt, B. M. 2012. STRUCTURE HARVESTER: A website and program for visualizing STRUCTURE output and implementing the Evanno method. Conserv. Genet. Res. 4:359-361.

21. Enjalbert, J., Duan, X., Giraud, T., Vautrin, D., De Vallavieille-Pope, C., and Solignac, M. 2002. Isolation of twelve microsatellite loci, using an enrichment protocol, in the phytopathogenic fungus Puccinia striiformis f. sp. tritici. Mol. Ecol. Notes 2:563-565.

22. Enjalbert, J., Duan, X., Leconte, M., Hovmøller, M. S., and De Vallavieille-Pope, C. 2005. Genetic evidence of local adaptation of wheat yellow rust (Puccinia striiformis f. sp. tritici) within France. Mol. Ecol. 14:2065-2073.

23. Evanno, G., Regnaut, S., and Goudet, J. 2005. Detecting the number of clusters of individuals using the software STRUCTURE: A simulation study. Mol. Ecol. 14:2611-2620.

24. Excoffier, L., Laval, G., and Schneider, S. 2005. Arlequin (version 3.0): An integrated software package for population genetics data analysis. Evol. Bioinf. 1:47-50.

25. Goudet, J. 1995. FSTAT (Version 1.2): A computer program to calculate F-statistics. J. Hered. 86:485-486.

26. Goyeau, H., Halkett, F., Zapater, M. F., Carlier, J., and Lannou, C. 2007. Clonality and host selection in the wheat pathogenic fungus Puccinia triticina. Fungal Genet. Biol. 44:474-483.

27. Haque, S., Park, R. F., Keiper, F. J., Bariana, H. S., and Wellings, C. R. 2008. Pathogenic and molecular variations support the presence of genetically distinct clonal lineages in Australian populations of Puccinia graminis f. sp. avenae. Mycol. Res. 112:663-673.

28. Hovmøller, M. S., and Justesen, A. F. 2007. Rates of evolution of avirulence phenotypes and DNA markers in a northwest European population of Puccinia striiformis f. sp. tritici. Mol. Ecol. 16:4637-47.

29. Hovmøller, M. S., Justesen, A. F., and Brown, J. K. M. 2002. Clonality and long-distance migration of Puccinia striiformis f. sp. tritici in northwest Europe. Plant Pathol. 51:24-32.

30. Hovmøller, M. S., Sorensen, C. K., Walter, S., and Justesen, A. F. 2011. Diversity of Puccinia striiformis on cereals and grasses. Annu. Rev. Phytopathol. 49:197-217.

31. Jin, Y. 2011. Role of Berberis spp. as alternate hosts in generating new races of Puccinia graminis and P. striiformis. Euphytica 179:105-108.

32. Jin, Y., Szabo, L. J., and Carson, M. 2010. Century-old mystery of Puccinia striiformis life history solved with the identification of Berberis as an alternate host. Phytopathology 100:432-435.

33. Line, R. F. 2002. Stripe rust of wheat and barley in North America: A retrospective historical review. Annu. Rev. Phytopathol. 40:75-118.

34. Line, R. F., and Qayoum, A. 1992. Virulence, aggressiveness, evolution, and distribution of races of Puccinia striiformis (the cause of stripe rust of wheat) in North America, 1968-1987. U. S. Dep. Agric. Bull. 1788.

35. Liu, J. Q., and Kolmer, J. A. 1998. Molecular and virulence diversity and linkage disequilibria in asexual and sexual populations of the wheat stripe rust fungus, Puccinia recondita. Genome 41:832-840.

36. Liu, M., and Hambleton, S. 2010. Taxonomic study of stripe rust, Puccinia striiformis sensu lato, based on molecular and morphological evidence. Fungal Biol. 114:881-899.

37. Liu, X., Huang, C., Sun, Z., Liang, J., Luo, Y., and Ma, Z. 2011. Analysis of population structure of Puccinia striiformis in Yunnan Province of China by using AFLP. Eur. J. Plant Pathol. 129:43-55.

38. Luig, N. H. 1985. Epidemiology in Australia and New Zealand. Pages 301-328 in: The Cereal Rusts Vol. II. Diseases, Distribution, Epidemiology, and Control. A. P. Roelfs and W. R. Bushnell eds. Academic Press, Orlando, FL.

39. Mboup, M., Leconte, M., Gautier, A., Wan, A. M., Chen, W., de Vallavieille-Pope, C., and Enjalbert, J. 2009. Evidence of genetic recombination in wheat yellow rust populations of a Chinese oversummering area. Fungal Genet. Biol. 46:299-307.

40. Murray, T. D., Chen, X. M., Roberts, D., and Jin, Y. 2011. Role of barberry in stem rust epidemics and race diversity in Washington and Idaho, U.S.A., 2007-2009. Pages 166 in: Oral Presentations, Poster Abstracts, Participants and Program of. BGRI Technical Workshop, St. Paul, MN

41. Nelson, R. J., Baraoidan, M. R., Cruz, C. M., Yap, I. V., Leach, J. E., Mew, T. W., and Leung, H. 1994. Relationship between phylogeny and pathotype for the bacterial blight pathogen of rice. Appl. Environ. Microbiol. 60:3275-3283.

42. Peakall, R. O. D., and Smouse, P. E. 2006. Genalex 6: Genetic analysis in Excel. Population genetic software for teaching and research. Mol. Ecol. Notes 6:288-295.

43. Pritchard, J. K., Stephens, M., and Donnelly, P. 2000. Inference of population structure using multilocus genotype data. Genetics 155:945959.

44. Roelfs, A. P. 1982. Effects of barberry eradication on stem rust in the United States. Plant Dis. 66:177-181.

45. Roelfs, A. P. 1985. Wheat and rye stem rust. Pages 3-37 in: The Cereal Rusts Vol. II. Diseases, Distribution, Epidemiology, and Control. A. P. Roelfs and W. R. Bushnell eds. Academic Press, Orlando, FL.

46. Rouse, M. N., Stoxen, S., Chen, X. M., Szabo, L. J., and Jin, Y. 2009. Diverse stem rust races found in a single field in Washington, USA. (Abstr.) Phytopathology 99:S111.

47. Samborski, D. J. 1985. Wheat leaf rust. Pages 39-59 in: The Cereal Rusts. 
Vol. II, Diseases, Distribution, Epidemiology, and Control. A. P. Roelfs and W. R. Bushnell eds. Academic Press, Orlando, FL.

48. Schuelke, M. 2000. An economic method for the fluorescent labeling of PCR fragments. Nat. Biotechnol. 18:233-234.

49. Sharma-Poudyal, D., Chen, X. M., Wan, A. M., Zhan, G. M., Kang, Z. S., Cao, S. Q., Jin, S. L., Morgounov, A., Akin, B., Mert, Z., Shah, S. J. A., Bux, H., Ashraf, M., Sharma, R. C., Madariaga, R., Puri, K. D., Wellings, C., Xi, K. Q., Wanyera, R., Manninger, K., Ganzález, M. I., Koyda, M., Sanin, S., and Patzek, L. J. 2013. Virulence characterization of international collections of the wheat stripe rust pathogen, Puccinia striiformis f. sp. tritici. Plant Dis. 97:379-386.

50. Steele, K. A., Humphreys, E., Wellings, C. R., and Dickinson, M. J. 2001. Support for a stepwise mutation model for pathogen evolution in Australasian Puccinia striiformis f. sp. tritici by use of molecular markers. Plant Pathol. 50:174-180.

51. Stubbs, R. W. 1985. Stripe rust. Pages 61-101 in: The Cereal Rusts, Vol. 2. Diseases, Distribution, Epidemiology and Control A. P. Roelfs and W. R. Bushnell, eds. Academic Press, Orlando, FL.

52. Wan, A. M., and Chen, X. M. 2011. Virulence, frequency, and distribution of races of Puccinia striiformis f. sp. tritici and P. striiformis f. sp. hordei Identified in the United States in 2008 and 2009. Plant Dis. 96:67-74.

53. Wan, A. M., and Chen, X. M. 2012. Stripe rust epidemics of wheat and barley and races of Puccinia striiformis identified in the United States in
2011. (Abstr.) Phytopathology 102:S4.130.

54. Wang, M. N., and Chen, X. M. 2013. First report of Oregon grape (Mahonia aquifolium) as an alternate host for the wheat stripe rust pathogen (Puccinia striiformis f. sp. tritici) under artificial inoculation. Plant Dis. 97:839.

55. Wang, M. N., Wan, A. M., and Chen, X. M. 2012. Genetic characterization of virulence/avirulence genes of Puccinia striiformis f. sp. tritici. (Abstr.) Phytopathology 102:S4:132.

56. Wang, M. N., Wan, A. M., Chen, X. M., and Evans, C. K. 2011. Barberry is more important as an alternate host for stem rust than for stripe rust in the U.S. Pacific Northwest. Page 166 in: Oral Presentations, Poster Abstracts, Participants and Program of BGRI Technical Workshop, St. Paul, MN.

57. Weir, B. S., and Cockerham, C. C. 1984. Estimating F-statistics for the analysis of population-structure. Evolution 38:1358-1370.

58. Wellings, C. R., and McIntosh, R. A. 1990. Puccinia striiformis f. sp. tritici in Australasia-Pathogenic changes during the 1st 10 years. Plant Pathol. 39:316-325.

59. Zhao, J., Wang, L., Wang, Z. Y., Chen, X. M., Zhang, H. C., Yao, J. N., Zhan, G. M., Chen, W., Huang, L. L., and Kang, Z. S. 2013. Identification of eighteen Berberis species as alternate hosts of Puccinia striiformis $\mathrm{f}$. sp. tritici and virulence variation in the pathogen isolates from natural infection of barberry plants in China. Phytopathology 103:935-940. 